Article

\title{
Assessing Diazinon Pollution in the Three Major Rivers Flowing into the Caspian Sea (Iran)
}

\author{
Reza Dahmardeh Behrooz ${ }^{1, *}$, Abbas Esmaili-sari ${ }^{2}$, Magdalena Urbaniak ${ }^{3}$ and Paromita Chakraborty ${ }^{4}$ D \\ 1 Department of Environmental Sciences, Faculty of Natural Resources, University of Zabol, Sistan 98914, Iran \\ 2 Department of Environmental Sciences, Faculty of Natural Resources and Marine Sciences, \\ Tarbiat Modares University, Nour, Mazandaran 46134, Iran; esmailisari@yahoo.com \\ 3 European Regional Centre for Ecohydrology of the Polish Academy of Sciences, Tylna 3, 90-364 Lodz, Poland; \\ m.urbaniak@unesco.lodz.pl \\ 4 Department of Civil Engineering and SRM Research Institute, SRM Institute of Science and Technology, \\ Kancheepuram District, Tamil Nadu 603203, India; paromitc@srmist.edu.in \\ * Correspondence: dahmardeh_behrooz@yahoo.com or dahmardehbehrooz@uoz.ac.ir; Tel.: +98-054-3323-2600; \\ Fax: +98-054-3323-2961
}

Citation: Dahmardeh Behrooz, R.; Esmaili-sari, A.; Urbaniak, M.; Chakraborty, P. Assessing Diazinon Pollution in the Three Major Rivers Flowing into the Caspian Sea (Iran). Water 2021, 13, 335. https://doi.org/ $10.3390 /$ w13030335

\section{Academic Editor:}

Helvi Heinonen-Tanski

Received: 27 November 2020

Accepted: 26 January 2021

Published: 29 January 2021

Publisher's Note: MDPI stays neutral with regard to jurisdictional claims in published maps and institutional affiliations.

Copyright: (C) 2021 by the authors. Licensee MDPI, Basel, Switzerland. This article is an open access article distributed under the terms and conditions of the Creative Commons Attribution (CC BY) license (https:/ / creativecommons.org/licenses/by/ $4.0 /)$.

\begin{abstract}
The aim of this study was to investigate the seasonal and spatial variations in the concentrations of a widely used organophosphorous pesticide (OPP), diazinon, and the associated risk posed by this OPP in the surface water from the three largest rivers located in the northern province of Iran: the Haraz, the Talar and the Babolrood rivers. These rivers are located in the agriculture province of Mazandaran, and are exposed to high doses of organophosphorus pesticides, especially diazinon. The concentration of diazinon was determined using gas chromatography, while the potential risk posed by diazinon was elucidated using a Risk Quotient (RQ) calculated for general (RQm) and worst-case (RQex) scenarios. The obtained results demonstrated that the average diazinon concentrations ranged from $41 \pm 76 \mathrm{ng} / \mathrm{L}$ in the Talar River and $57 \pm 116 \mathrm{ng} / \mathrm{L}$ in the Haraz River, to $76.5 \pm 145 \mathrm{ng} / \mathrm{L}$ in the Babolrood River, with a significant difference noted between summer and autumn seasons for all three rivers. For some stations, the concentration of diazinon is higher than the standard guidelines of Australian/New Zealand Guidelines for Fresh and Marine Water Quality (FMWQ) and the United States Criteria Maximum Concentration (CMC). The calculated RQs indicated a medium risk of diazinon, $\mathrm{RQm}=0.73$ and $\mathrm{RQex}=2.27$, in the Talar River; $\mathrm{RQm}=1.02$ and RQex = 2.49 in the Haraz River; and RQm = 1.35 and RQex = 4.54 in the Babolrood River. The overall exposure of diazinon was defined to have a high risk (RQm and RQex $>1$ ); however, the summer sampling revealed a high risk (RQm and RQex $>1$ ), while the autumn had a medium risk (RQm and RQex $<1$ ). The obtained results revealed not only elevated concentrations of diazinon in the studied rivers but most importantly the high risk posed by this OPP for the aquatic organisms and the wellbeing of the whole river ecosystem. The current study showed that development and implementation of appropriate standards and regulations toward diazinon in countries such as Iran are required to reduce the pollution levels and risks related to elevated concentrations of the studied pesticide.
\end{abstract}

Keywords: diazinon; risk quotient; riverine ecosystem; aquatic; South Caspian Sea; Iran

\section{Introduction}

Around 2,540,117 tons of pesticides are consumed every year across the world to protect crops against pests and diseases, to shelter human from insect and pest bites, and also to preserve agricultural products in warehouses (commercial applications) and in homes [1]. Such a high usage of pesticides can threaten the health of consumers in addition to the environment $[2,3]$.

Among the most commonly used groups of pesticides are organic phosphorus pesticides (OPPs), characterized by high resistance in the environment and toxicity to liv- 
ing organisms [4-9]. Diazinon (O,O-Diethyl O-[4-methyl-6-(propan-2-yl)pyrimidin-2yl]phosphorothioate) is a pesticide from the OPPs group widely used in agricultural and non-agricultural activities. The pesticide is moderately persistent, but highly mobile in the environment. Moreover, it is considered to be highly toxic for vertebrates, decreasing their diversity in the ecosystem $[6,10,11]$. Nowadays, diazinon is the main insecticide used to control stem boring caterpillar of rice (Chilo supressalis), lice, blowflies, ked, ticks in sheep, cattle, goats, dogs and so on. It controls aphids, caterpillars, moths, butterflies, various worms, locusts, grasshoppers and scale in pastures, orchards, vegetables and field crops.

To avert health risks associated with OPPs, including diazinon, a restriction for its usage has been imposed by the United States Environmental Protection Agency (US EPA). Thus, since 2005, it has become illegal to sell non-agricultural products containing diazinon [12]. Consequently, nowadays, the main sources of OPPs in the environment are related to the agricultural use of these pesticides. They can enter the aquatic environments via surface runoff from cultivated lands and as an effect of agricultural sewage discharge and dumped waste [13-15]. As an effect of their high solubility in water, these pesticides are highly mobile. Their principal receivers are aquatic environments, such as rivers or lakes, wherein OPPs can exert a threat to biodiversity and proper ecosystem functioning [15-22]. Therefore, investigation of the levels of OPPs, including diazinon, in aquatic ecosystems subjected to agricultural pollution is of vital importance to protect and maintain these ecosystems for future generations.

In Iran, the Mazandaran province is among the most important agricultural areas, producing $45 \%$ of Iran's rice and also consuming $19 \%$ of the total country's pesticides. Mazandaran agricultural sectors have noted pervasive usage of insecticides, especially in rice/paddy fields, mainly in the summer months $[23,24]$. The yearly agricultural usage of pesticide in this region is as high as $\sim 30 \times 10^{3}$ tons [25]. This, together with the fact that rice farming requires flood submersion during the entire growing season, facilitates the pathways for pesticides to enter and contaminate the surrounding river ecosystems [23,26,27]. In the Mazandaran region, most of the rice fields are fed by three main rivers: the Haraz, the Talar and the Babolrood. Thus, given the high volume of agricultural activity in this region and the wide usage of diazinon, which accounts for up to $60 \%$ of the total pesticide usage in Iran, the monitoring of the concentrations of this pesticide, together with an evaluation of the risk it can pose to the riverine ecosystems of this area, is of high importance.

Considering the above, our objectives were to (i) evaluate the pollution status of the three main rivers in Iran, the Haraz River, the Talar River and the Babolrood River, in terms of the diazinon concentrations; (ii) demonstrate the seasonal and spatial changes in the pesticide concentrations; and (iii) assess the potential risk aquatic organisms associated with the presence of the pesticide in the three river ecosystems.

\section{Material and Methods}

\subsection{Locations of Sampling Stations}

This study was conducted along the Haraz, the Talar and the Babolrood rivers located in the northern part of Iran (Figure 1).

The rivers originated from the Alborz Mountain and flow into the Caspian Sea. The rivers are located in the area of uneven precipitation throughout the year with $8 \%, 19 \%$, $48 \%$ and $25 \%$ falling in spring, summer, fall and winter, respectively [28]. For the period 1951-2013, the average yearly precipitation reached in the region was $729 \mathrm{~mm}$, with an average 114 rainy days during a year.

The Haraz is the longest of the three rivers. It flows into the Caspian Sea after passing through a range of villages, and the cities of Amol and Sorkhrud. The length of the river is $185 \mathrm{~km}$, the catchment area size is $2000 \mathrm{~km}^{2}$ and the river discharge is $30.18 \mathrm{~m}^{3} / \mathrm{s}$ (in 2006). The maximum and minimum elevation of the river is 5600 and $200 \mathrm{~m}$, respectively, with a slope of $10 \%$. The width of the river varies between 50 and $500 \mathrm{~m}$. The average yearly precipitation is $832 \mathrm{~mm}$ [29-31]. 


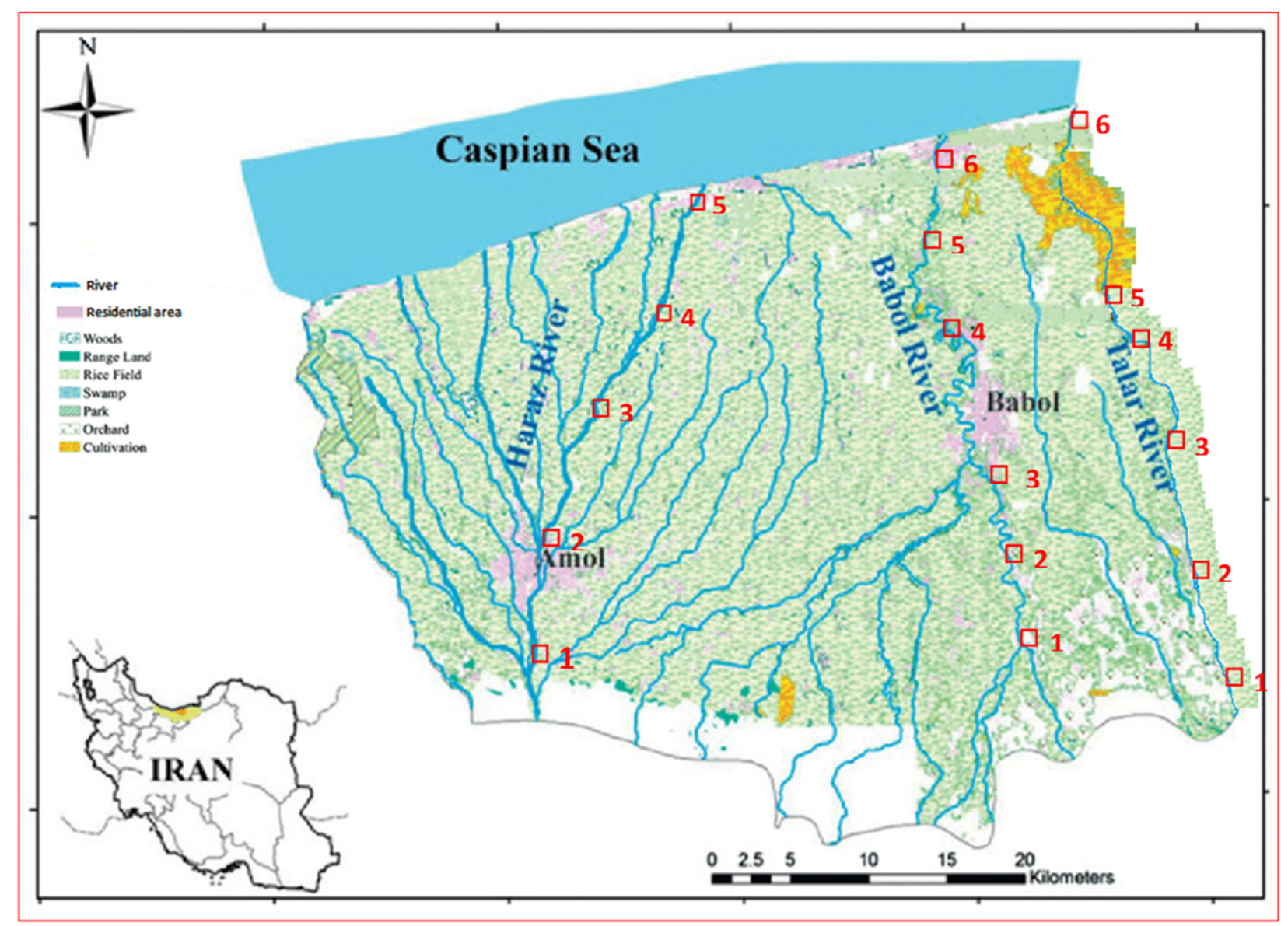

Figure 1. Sampling stations along the Talar, the Haraz and the Babolrood rivers.

The length of the Talar River is $150 \mathrm{~km}$, and its catchment covers an area of about $2845 \mathrm{~km}^{2}$. The river source is $3850 \mathrm{~m}$ above sea level [32]. It has a variable width ranging between 30 to $60 \mathrm{~m}$, and its slope is about $7 \%$. The river passes through a range of villages and the vicinity of Ghaemshahr city with a population of 320,741 inhabitants.

The Babolrood River is located in the Savadkouh district of Mazandaran Province in the Alborz Mountains near the Caspian Sea. The river is $161 \mathrm{~km}$ long with a catchment area of $1659 \mathrm{~km}^{2}$ [33] and a maximum and minimum elevation of 3180 and $10 \mathrm{~m}$, respectively. Ninety percent of the catchment is located at elevation $2200-2900 \mathrm{~m}$. The slopes of the catchment have been categorized into five classes with the largest proportion of the slopes ranging between $30 \%$ and $60 \%$, whereas slopes less than $5 \%$ are least common. The river has a variable width from 40 to $60 \mathrm{~m}$, and its annual mean discharge varies from 3.44 to $16.67 \mathrm{~m}^{3} / \mathrm{s}$. The river flows as the valley river with the remarkable slope of $7 \%$ [34].

The Haraz River is located in the catchment with strong touristic and industrial sectors. Most restaurants and industrial centers dump their sewage into this river. Aquaculture and agriculture play minor roles. The Talar and Babolrood rivers, in turn, are located in prevailing agricultural catchments with influences of industry and aquaculture.

\subsection{Collection of Samples}

High-grade amber glass bottles (1 L) were used to collect the samples of depth 30 to $50 \mathrm{~cm}$ from the surface of the water. There was a total of 204 samples. Sampling was performed always twice a month in each station, resulting in 60,72 and 72 samples collected from Haraz, Talar and Babolrood rivers, respectively, during the two-season study period in 2008 (in summer: July, August and September; in autumn: October, November and December) (Figure 1). The glass jar was cleaned with distilled water first and then rinsed with acetone and hexane in sequence to remove a trace number of organic contaminants. 
The bottles were rinsed with the river water before collecting the samples, and water samples were collected in glass jars to fill them completely in order to avoid air bubbles. Samples were transported to the laboratory wherein $\mathrm{pH}$ was measured (it was found that $\mathrm{pH}$ of all collected samples ranged from 7.1 to 7.4), and the samples were passed through separate filter papers (Schleicher and Schuell 589.3, Göttingen, Germany) and then through a $0.5 \mu \mathrm{m}$ glass microfiber filter to remove particulate matter. The samples were stored at a temperature of $4{ }^{\circ} \mathrm{C}$ and analyzed within 3 days.

\subsection{Analytical Procedures, Quantification and Quality Assurance}

The diazinon standard, obtained from Riedel-de Han (Seelez, Germany), was used to prepare the stock solution $(1 \mathrm{mg} / \mathrm{L})$. Pentachloronitrobenzene $(\mathrm{PCNB})$ was used as an internal standard ( $5 \mathrm{mg} / \mathrm{L}$ sample). In the first stage, a volume $300 \mathrm{~mL}$ of river water was passed through a Whatman cellulose filter paper and was eluted using solid-phase extraction (SPE) manifold of Envir Elut PAH (6 mL, 1 g) cartridges (Waters, Milford, MA, USA) for extraction. Conditioning was performed using methanol followed by distilled water, and the sample was passed $(10 \mathrm{~mL} / \mathrm{min})$ and dried under vacuum $[35,36]$. An amount of $15 \mathrm{~mL}$ of dichloromethane was used as an eluting solvent, and the eluate was further passed through $\mathrm{Na}_{2} \mathrm{SO}_{4}$ to remove any moisture [36,37]. Samples were dried using nitrogen at $50{ }^{\circ} \mathrm{C}$, then the residues were diluted with $0.3 \mathrm{~mL}$ of $\mathrm{n}$-hexane, and the obtained samples were stored at $-20^{\circ} \mathrm{C}$ for further analysis.

Gas chromatography (GC) model 1000, DANI Co., Italy, equipped with a nitrogenphosphorous detector (NPD) was used for quantification. Helium as carrier gas $(99.999 \%$ purity) at $3.6 \mathrm{~mL} / \mathrm{min}$ flowrate and an Optima 5 column $(6 \mathrm{~m} \times 0.25 \mathrm{~mm}$ id $\times 0.25 \mu \mathrm{m})$ was used for this method. Injector and detector temperatures were kept at 250 and $320^{\circ} \mathrm{C}$, respectively. The injection volume of $1 \mu l$ was used, and the oven temperature was increased from 100 to $300{ }^{\circ} \mathrm{C}$ in a total time run time of $40 \mathrm{~min}$.

Limits of quantification (LOQs) of the used method were measured in spiked samples and calculated by considering $3 \times$ procedural blank, calculated as $0.09 \mathrm{ng} / \mathrm{L}$. Each analyte was identified based on the retention time from the calibration standards. To achieve high quality results, the analysis blank was used within each sample batch; moreover, the concentration of diazinon $>0.1$ (LOQ) was used for all tested analytes. Three samples of standard reference material were used for the accuracy of total diazinon analysis via GC, and the mean recovery of this pesticide in water was $86 \%$.

A calibration curve was prepared for the quantitative determination of diazinon by plotting the peak areas of the detector versus the concentrations of spiked diazinon in methanol. The correlation range was at least 0.99 , and the LOD $(3 \mathrm{~S} / \mathrm{N})$ was $0.03 \mathrm{ng} / \mathrm{L}$ with RSD $<8 \%(n=5)$. Quantification was based on a comparison with calibration curves in the concentration of $0.1,1,10,100,400$ and $800 \mathrm{ng} / \mathrm{L}$.

\subsection{Aquatic Risk Assessment}

In this study, the aquatic risk assessment of diazinon was performed using a deterministic risk quotient $(R Q)$ method $[21,38,39]$ based on equation $R Q=M E C / N O E C$, where MEC is the measured environmental concentration and NOEC is the no-observed effect concentration. The no-observed effect concentration (NOEC) was for three trophic levels, (1) primary producers, i.e., algae $\left(10 \times 10^{7} \mathrm{ng} / \mathrm{L}\right)$; (2) primary consumers, i.e., aquatic invertebrates (560 ng/L); and (3) secondary consumers, i.e., fish $\left(7 \times 10^{5} \mathrm{ng} / \mathrm{L}\right)$ [40,41]. The potential risk posed by diazinon was elucidated using the above Risk Quotient (RQ) calculated for general (RQm) and worst-case (RQex) scenarios. In our study, in the first stage, two scenarios were tested on base NOEC: in the first scenario, we used the mean diazinon concentration that corresponds to RQm, and in the second scenario, we used the maximum level of diazinon that corresponds to the worst-case scenario (RQex) as follows:

$\mathrm{RQm}=\mathrm{MEC}$ (mean concentration diazinon/NOEC);

RQex = MEC (maximum concentration diazinon/NOEC). 
In the second stage of this study, the RQm and RQex of diazinon were performed based on equation RQm and RQex = MEC/PNEC, where MEC is the measured environmental concentration and PNEC is the predicted no-effect concentration. PNEC is derived from the lowest toxicity value (i.e., no-observed effect concentration (NOEC) value) observed for the most sensitive species, and an assessment factor of 10 was applied based on the available data on long-term toxicity NOECs of aquatic invertebrates $[40,41]$. Further, risk levels were divided into four categories: high $(\mathrm{RQ} \geq 1)$, medium $(0.1 \leq \mathrm{RQ}<1)$, low $(0.01 \leq \mathrm{RQ}<0.1)$ and negligible risk $(\mathrm{RQ}<0.01)[38,42]$. RQs for diazinon in surface water of the three rivers are depicted in Section 3.2 .

\subsection{Statistical Analysis}

The non-detectable concentrations were substituted with zero while calculating the mean concentrations of diazinon in surface water samples from rivers and for statistical purposes $(<\mathrm{LOQ}=0$, i.e., lower bound, $\mathrm{LB})$. The data were tested for normality using a Kolmogorov-Smirnov test and were found to be normally distributed after log transformation. The variability of the dataset among stations was evaluated using one-way analysis of variance (ANOVA; Tukey test). Diazinon concentration between stations for each season was subjected to an independent $t$-test. For statistical analysis, the SPSS Software (Version 16.5, Chicago, IL, USA) was utilized with $p<0.05$.

\section{Results and Discussion}

3.1. Seasonal and Spatial Distribution of Diazinon in the Talar, Babolrood and Haraz Rivers

The concentrations of diazinon in the water samples from the Haraz, the Talar and the Babolrood rivers ranged from below detection limit to $650 \mathrm{ng} / \mathrm{L}$. The highest value of $650 \mathrm{ng} / \mathrm{L}$ was noted in the Babolrood River, followed by $497 \mathrm{ng} / \mathrm{L}$ measured in the sample from the Haraz River and $457 \mathrm{ng} / \mathrm{L}$ in the Talar River (Table 1).

Table 1. Concentration of diazinon in the surface water of the Haraz, Talar and Babolrood rivers (ng/L).

\begin{tabular}{|c|c|c|c|c|c|}
\hline & Number Sample & Season & Mean $\pm S D$ & Minimum & Maximum \\
\hline \multirow[t]{3}{*}{ Haraz River } & 30 & Summer & $98 \pm 153 *$ & $<\mathrm{LOQ}$ & 497 \\
\hline & 30 & Autumn & $16 \pm 22$ & $<\mathrm{LOQ}$ & 77 \\
\hline & 60 & Two seasons & $57 \pm 116$ & $<\mathrm{LOQ}$ & 497 \\
\hline \multirow[t]{3}{*}{ Talar River } & 36 & Summer & $72 \pm 95$ * & $<\mathrm{LOQ}$ & 457 \\
\hline & 36 & Autumn & $10 \pm 23$ & $<\mathrm{LOQ}$ & 134 \\
\hline & 72 & Two seasons & $41 \pm 76$ & $<\mathrm{LOQ}$ & 457 \\
\hline \multirow[t]{3}{*}{ Babolrood River } & 36 & Summer & $140 \pm 183 *$ & $<\mathrm{LOQ}$ & 650 \\
\hline & 36 & Autumn & $11 \pm 21$ & $<\mathrm{LOQ}$ & 90 \\
\hline & 72 & Two seasons & $76.5 \pm 145$ & $<\mathrm{LOQ}$ & 650 \\
\hline Total & 204 & Total & $58 \pm 116$ & $<\mathrm{LOQ}$ & 650 \\
\hline
\end{tabular}

* results statistically significant.

The average concentrations of diazinon residues ranged from $41 \pm 76 \mathrm{ng} / \mathrm{L}$ in the Talar River and $57 \pm 116 \mathrm{ng} / \mathrm{L}$ in the Babolrood River, up to $76.5 \pm 145 \mathrm{ng} / \mathrm{L}$ in the Haraz River. The obtained results revealed strong variations between seasons, with a 6 to 13fold higher average concentration of diazinon in samples collected in the summer season (Table 1). The findings also demonstrated significant differences between the studied rivers in the summer season; no such difference was noted in autumn nor the whole sampling season (summer + autumn) (Table 1).

The monthly variation of diazinon in the studied rivers showed elevated levels specifically in July and August (Figure 2). 


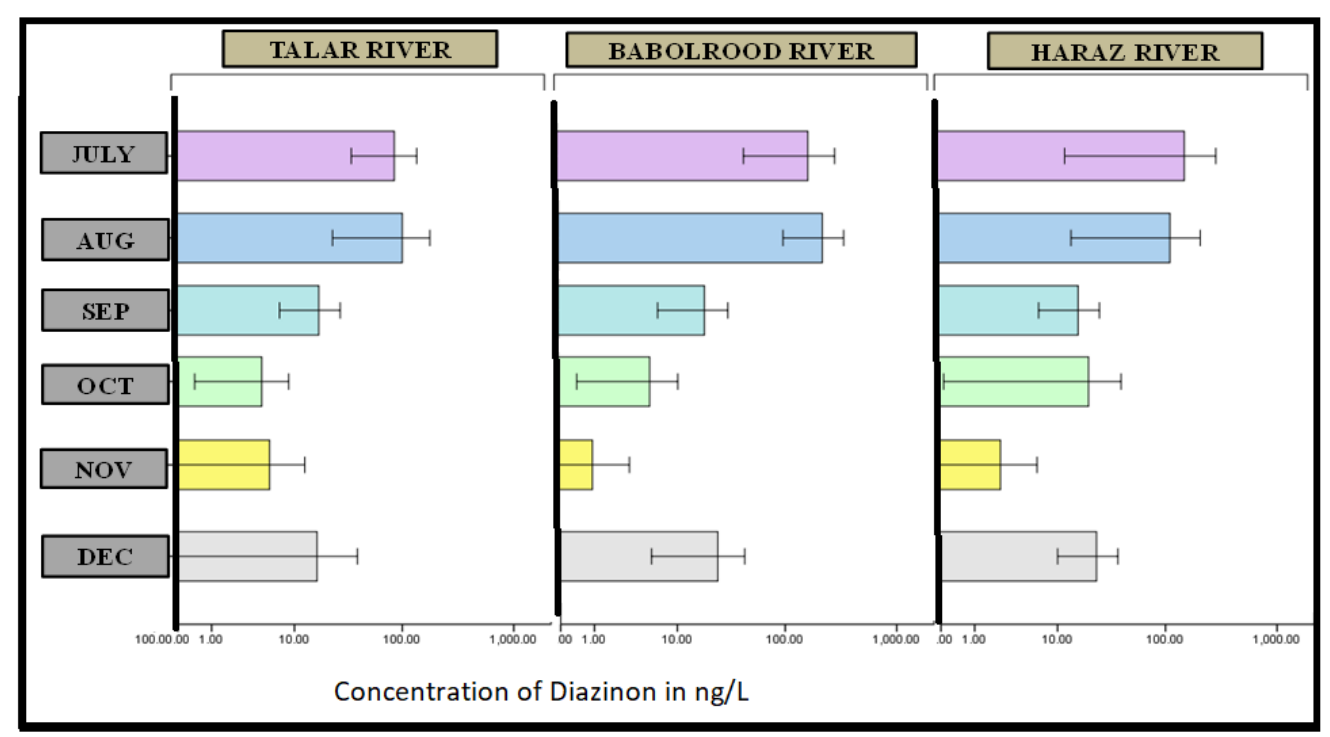

Figure 2. Monthly distribution of diazinon in the Talar, Babolrood and Haraz rivers.

It is interesting to note that more than $80 \%$ of diazinon was contributed from the month of July and August together in all the three rivers. Additionally, the concentration of diazinon noted in July and August was significantly different $(p<0.05)$ than levels noted in September, October, November and December for all the three rivers. A distinct increase in the concentration of diazinon in December was observed in all the three rivers. A significant increase $(p<0.05)$ in the total concentration of diazinon from July to August was observed in the Talar River followed by a continual decrease in the following months. A similar trend in concentration was reported in the Babolrood River. On the contrary, a significant decrease $(p<0.05)$ in the level of the total concentration of diazinon from July to August was observed in the Haraz River. Considering stationwise variation in the Haraz, the Talar and the Babolrood, we did not observe any significant difference in the variation of concentrations along all the stations. A higher abundance of total diazinon in the Talar River (32\%) was observed at station 6. For the Babolrood River, elevated levels were reported at station $1(23 \%)$. Approximately $45 \%$ dominance of diazinon was reported at station 5 in the Haraz River, and all of these stations were located in areas where fields were cultivated with rice, and diazinon was used to protect the crop from pests. The lowest total concentration of diazinon was observed in November for the rivers Babolrood and Haraz. Unlike the Babolrood and the Haraz rivers, the lowest concentration of diazinon in the Talar River was observed in October.

Regarding spatial distribution of diazinon, our results showed that more than $44 \%$ of total diazinon in the present study was from the Babolrood River, and the maximum mean concentration in this river was observed at station $1(107 \pm 207 \mathrm{ng} / \mathrm{L})$ followed by station 5 $(85 \pm 167 \mathrm{ng} / \mathrm{L})$. Interestingly, the maximum mean diazinon concentration was observed in the Haraz River at station $5(127 \pm 180 \mathrm{ng} / \mathrm{L})$ followed by station $4(112 \pm 154 \mathrm{ng} / \mathrm{L})$, demonstrating an increasing trend in the pesticide concentration downstream. The total diazinon reported in the Haraz River was approximately 33\%. Moreover, station 5 contributed proximally $37 \%$ of total diazinon reported in the Haraz River. There was an increasing trend in the concentration of diazinon from station 1 to station 6 in the Talar River. A similar increasing trend in the concentration of diazinon was evident in the Haraz River. This finding increases the problem of coastal water contamination by diazinon. Unlike the rivers Haraz and Talar, the Babolrood River had comparatively consistent levels of diazinon concentration with a lower observed trend specifically in the middle stretch of the river.

The river basins of the three studied rivers are covered by agricultural lands and aquaculture. Research has shown high pesticide contamination via surface runoff to the nearby rivers, where adjoining landmasses were intensively used for agricultural 
activity $[43,44]$. The obtained levels of diazinon were similar to concentrations noted in other rivers in Iran, such as River Hendo Khale (62-270 ng/L) [23], Siahrood (50$220 \mathrm{ng} / \mathrm{L})$ [27], Tajan River (0.01-50 ng/L) [45] and lower Babolrood (77-600 ng/L) [46].

Compared with other rivers of the world, the levels of diazinon obtained in our study were similar to Guadalquivir River in Spain, ranging from 1.2 to $456.72 \mathrm{ng} / \mathrm{L}$ [18], and Kalamas River in Greece ranging from 40 to $250 \mathrm{ng}$ /L [47], but higher than concentrations noted in Guadiana River in Portugal: 0.54-4.25 ng/L [38]; Litani River in Lebanon: 2.8-9.7 ng/L [48]; Sarno River in Italy: 0.32-2.01 ng/L [19]; Tighra Reservoir in India: ND-16.2 ng/L [13]; Yangtse River in China: 1.3-16 ng/L [49]; Pearl River in China: 1.3$28.8 \mathrm{ng} / \mathrm{L}$ [49]; Langat River in Malaysia: 9.4-37.2 ng/L [2], and much lower than the level reported from Damietta Canal in Egypt: 705,000 ng/L [50] and Selangor River in Malaysia: $116.1-510.0 \mathrm{ng} / \mathrm{L}$ [51].

In our study, no significant differences were found between six sampling stations in the three rivers; however, the diazinon levels were significantly different in summer and autumn $(p<0.05)$ at all six sampling stations in the studied rivers. This difference was due to the use of diazinon pesticide for rice cultivation in Northern Iran. Overall, a higher concentration in the summer months (dry season) than the autumn months (wet season) might be due to a higher dilution factor in the latter (Table 1) [23,24,52-54]. Additionally, studies of diazinon in rice fields in Northern Iran showed that the highest concentration of diazinon was in September, while in November, diazinon was not detected in water samples; these findings are similar to the results obtained in river water in our study [24]. Similar results were obtained in Qazvin province of Iran: the mean concentration of diazinon in water of Shahrood river was $4120 \mathrm{ng} / \mathrm{L}$ (ND—9950 ng/L), and higher levels were detected in the areas located close to rice fields wherein diazinon is commonly used [55]

\subsection{Risk Assessment}

Diazinon is known to induce cytotoxicity, lipid peroxidation, fragmentation of DNA and damage to humans due to oxidation damage through the generation of free radicals and induces lipid peroxidation and DNA fragmentation [56]; on the other hand, studies have shown that human exposure to diazinon can cause incidence of cancer in human $[57,58]$. Studies showed promoted effects of diazinon on reduced species richness and enhanced sporulation of fungus, and increased mortality of amphipod and reduced shredding performance [59].

In our study, two scenarios were tested: in the first scenario, we calculated the RQm and RQex these rivers based on NOEC, and in the second scenario, we calculated these based on PNEC.

Based on the NOEC values, maximum risk was found for invertebrates during summer (Figure 3). However, excluding one site in Talar River, all other sites were below the level to cause any hazardous or harmful impact. On the other hand, based on PNEC in all three rivers, the aforementioned RQ method was employed. The observed RQs for the Talar River were $\mathrm{RQm}=0.73$ and RQex $=2.27$; for the Babolrood River: $\mathrm{RQm}=1.35$ and RQex $=4.54$; and for the Haraz River: RQm $=1.02$ and RQex $=2.49$. Based on the two sampling seasons, the diazinon exposure was at medium risk in the Talar River $(0.1 \leq R Q<1)$, while in the Babolrood and Haraz rivers, the risk posed by diazinon was calculated as high $(R Q \geq 1)$ (Figure 4). The calculated $R Q$ values indicate that the evaluated aquatic organisms are at medium (the Talar River) to high risk (the Babolrood and Haraz rivers). The high level is probably due to the abundant agricultural lands around these rivers that have been cultivated with rice and the use of diazinon pesticides in these lands. 


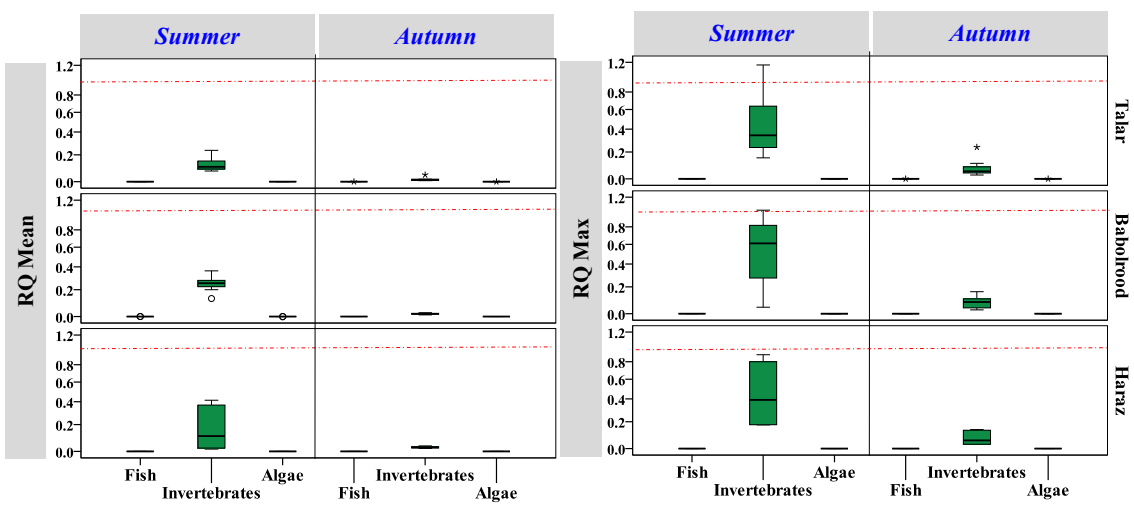

Figure 3. Estimated Risk Quotient (RQ) for different trophic levels in Talar Babolrod and Haraz rivers in Iran. * A high calculated risk number in a sampling.

\begin{tabular}{|c|c|c|c|c|c|c|c|}
\hline Stations & S1 & S2 & \multicolumn{2}{|c|}{ S3 } & S4 & S5 & $\begin{array}{c}\text { Average } \\
\text { All stations }\end{array}$ \\
\hline RQm summer & 0.17 & 0.23 & \multicolumn{2}{|c|}{0.50} & 3.69 & 4.14 & 1.75 \\
\hline RQm autumn & 0.32 & 0.24 & \multicolumn{2}{|c|}{0.21} & 0.30 & 0.38 & 0.29 \\
\hline RQm total & 0.24 & 0.23 & \multicolumn{2}{|c|}{0.36} & 1.99 & 2.26 & 1.02 \\
\hline RQex summer & 0.45 & 0.73 & \multicolumn{2}{|c|}{1.75} & 8.00 & 8.88 & 3.96 \\
\hline RQex autumn & 0.84 & 0.82 & \multicolumn{2}{|c|}{0.77} & 1.38 & 1.32 & 1.02 \\
\hline RQex total & 0.64 & 0.78 & \multicolumn{2}{|c|}{1.26} & 4.69 & 5.10 & 2.49 \\
\hline Stations & S1 & S2 & \multicolumn{2}{|l|}{ S3 } & S5 & S6 & $\begin{array}{c}\text { Average } \\
\text { All stations }\end{array}$ \\
\hline RQm summer & 1.02 & 1.07 & 0.75 & 0.79 & 1.72 & 2.37 & 1.29 \\
\hline RQm autumn & 0.10 & 0.12 & 0.17 & 0.07 & 0.08 & 0.48 & 0.17 \\
\hline RQ total & 0.56 & 0.59 & 0.46 & 0.43 & 0.90 & 1.42 & 0.73 \\
\hline RQex summer & 2.32 & 3.43 & 2.41 & 1.54 & 4.75 & 8.16 & 3.77 \\
\hline RQex autumn & 0.50 & 0.52 & 0.59 & 0.27 & 0.32 & 2.39 & 0.76 \\
\hline RQex total & 1.41 & 1.97 & 1.50 & 0.90 & 2.54 & 5.28 & 2.27 \\
\hline RQex total & 0.96 & 1.25 & 1.04 & 0.58 & 1.43 & 3.83 & 1.52 \\
\hline Stations & s1 & S2 & S3 & S4 & S5 & S6 & $\begin{array}{c}\text { Average } \\
\text { All stations }\end{array}$ \\
\hline RQm summer & 3.60 & 2.00 & 2.50 & 1.30 & 2.90 & 2.60 & 2.50 \\
\hline RQm autumn & 0.18 & 0.27 & 0.26 & 0.19 & 0.12 & 0.13 & 0.19 \\
\hline RQ total & 1.90 & 1.10 & 1.40 & 0.70 & 1.50 & 1.40 & 1.30 \\
\hline Rqex summer & 11.60 & 5.10 & 7.50 & 6.10 & 8.90 & 10.20 & 8.20 \\
\hline Rqex autumn & 1.11 & 1.61 & 1.29 & 0.41 & 0.27 & 0.41 & 0.85 \\
\hline RQex total & 6.40 & 3.40 & 4.40 & 3.30 & 4.60 & 5.00 & 4.50 \\
\hline
\end{tabular}

Figure 4. RQm, RQex and RQ total (the mean of the two seasons) of diazinon in the Haraz River (A), the Talar River (B) and the Babolrood River (C). Color indications: red-high risk; yellow-medium risk; green-low risk. 
The obtained RQs were higher than those obtained for the Langat River in Malasia $(\mathrm{RQm}=0.17$ and RQex $=0.66)$ [2], the Tiber River in Italy $(\mathrm{RQm}=0.05$ and RQex $=0.75)[21]$, the Acheloos River in Greece (RQm = 0.55 and RQex = 1.26) [60] and Lake Amvrakia in Greece $(\mathrm{RQm}=0.10$ and $\mathrm{RQex}=0.94)$ [14].

A significant difference $(p<0.05)$ in risk was observed between summer and autumn seasons in all the three rivers with an increased ecological risk during summer. The occurrence of OPPs in surface water was influenced by extreme meteorological events coupled with hydrological events and seasonal agricultural practices [21]. A higher level of diazinon is of greater concern in the summer months due to its adverse effect on juvenile organisms, especially fishes.

Based on RQs calculated for all sites in the three rivers (Figure 4), in the Babolrood River, diazinon was present at a higher number of stations, posing high risk (RQs $>1)$ for both the general (RQm using mean MEC) and worst-case scenarios (RQex using maximum MEC). It should be noted that the proportions of samples classified as high risk from diazinon in surface water of the Babolrood River were 5 out of 6 stations in the general scenario and all stations for worst-case scenarios (Figure 4).

Baseline investigation of exposure-related toxicity is the prime step in formulating legislation and policies related to risk mitigation. In this context, there is a growing concern in Iran regarding the exposure and toxicity of diazinon, especially in the aquatic ecosystems, mainly due to the paucity of data. Various risk assessment methods are used based on the availability of data, approach undertaken for assessment and whether the risk is associated with ecology or human health [61]. However, the synergistic/antagonistic effects of pesticide mixtures cannot be ruled out [62]. In this study, we assessed only one OPP. Nevertheless, the synergistic effect of other pesticides is an important concern that needs to be surveyed since it can promote deleterious effects on aquatic organisms' wellbeing, although the exact mechanisms are yet to be determined [63]. Hence, extensive research is required on the synergistic effects of OPP mixtures. The paucity of risk assessment research may have a negative effect on future efforts pertaining to monitoring and management. Currently, the regulatory framework and policy amendments are needed to scale down the levels of OPP in surface water. In addition to exposure and toxicity studies, levels associated with risk guidelines and standards are essential for effective decision making.

\subsection{International Quality Standards for Diazinon}

Implementation of quality standards in the USA and the European Union regarding diazinon in the environment was mainly due to the toxic effects of the pesticide on human health and living organisms, especially aquatic organisms. To mitigate the risk of diazinon on the environment, the European Union has introduced several regulations (i.e., Regulations 793/93 and 1488/94) and directives (i.e., Directive 67/548, 93/67 and Directive 98/8). The maximum diazinon level of $170 \mathrm{ng} / \mathrm{L}$ was also established by the United States Criteria Maximum Concentration (CMC), while Australian and New Zealand Guidelines for Fresh and Marine Water Quality (FMWQ) proposed the level of $100 \mathrm{ng} / \mathrm{L}$. However, regional regulation on the levels and distribution of pollutants might be of limited scope in other parts of the world due to the differences in usage, sources and meteorological factors [21].

Overall, levels of diazinon collected from the three rivers were below the US and Australian standards (Figure 5). On the other hand, when surveyed separately in summer, when the farmers used diazinon on rice fields, the pesticide concentrations exceeded the CMC and FMWQ at some stations in the Talar (S6) and Haraz rivers (S4 and S5). In the Babolrood River, diazinon concentrations were higher than the above standards in all stations except S4 (exceeded FMWQ) and S1 (exceeded the CMC) (Figure 5). The increased concentration of diazinon at the sampling points located downstream close to the Caspian Sea (stations 4-6) raises concern about the concentration of this pesticide in the coastal waters. 


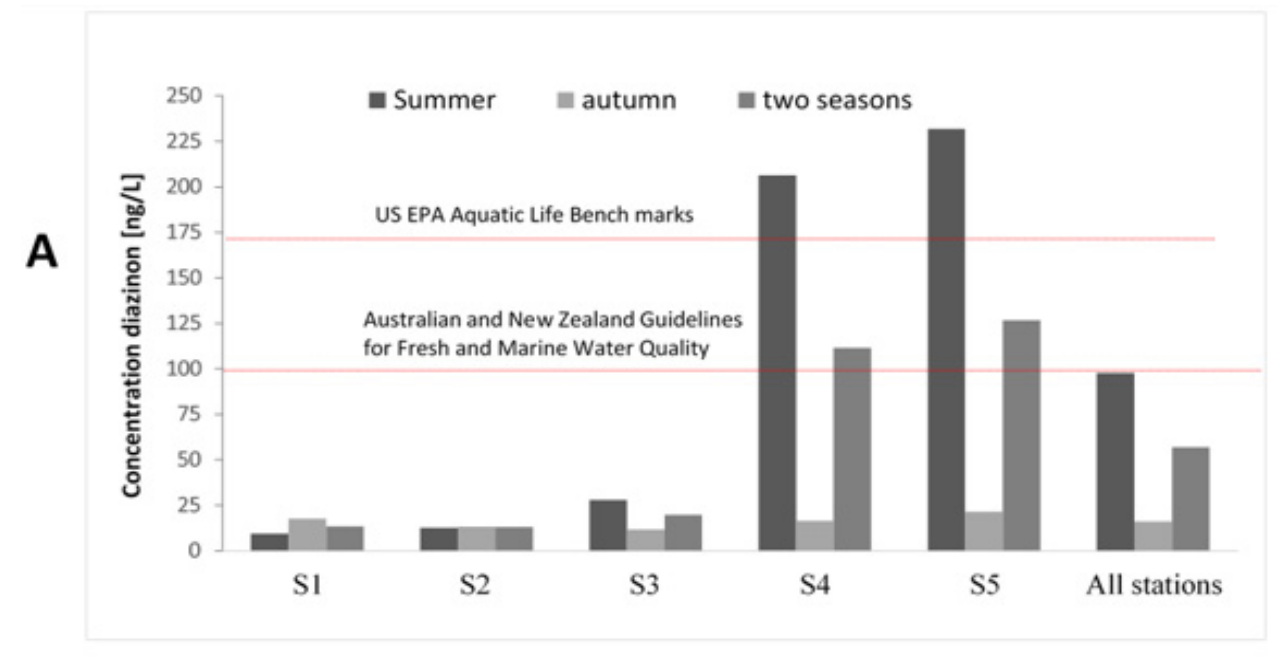

B

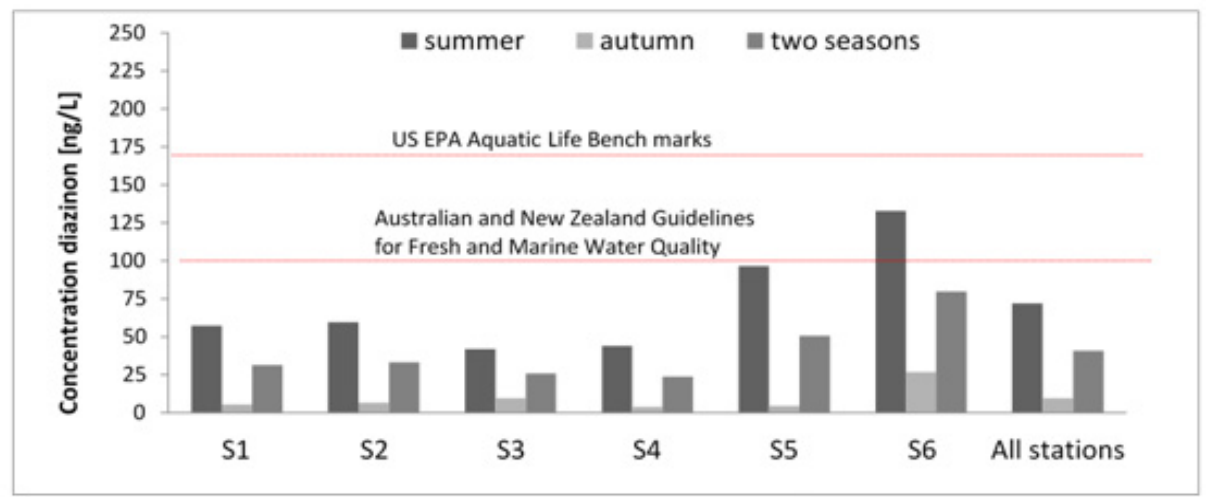

C

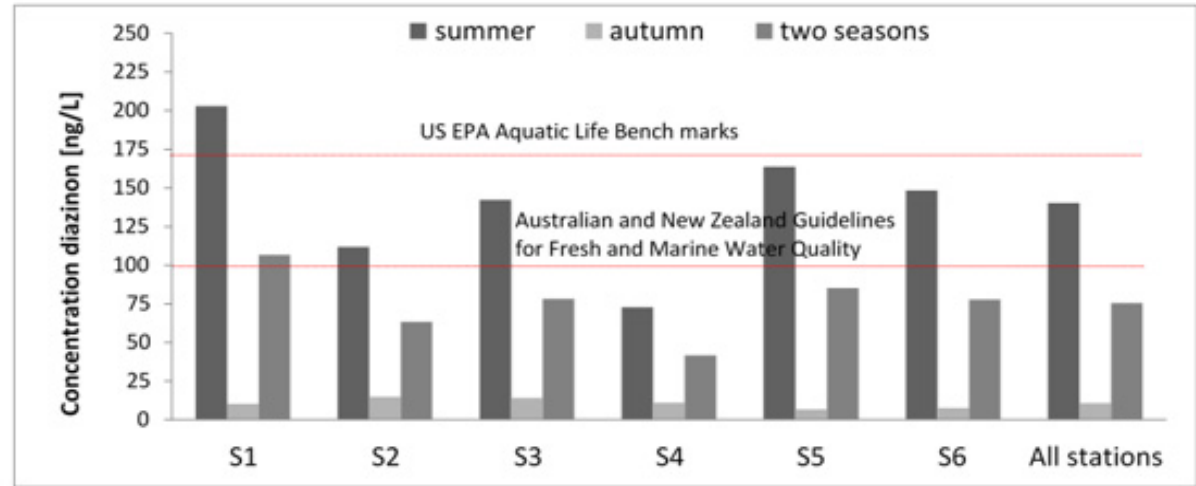

Figure 5. Mean concentration of diazinon in the surface water of the Haraz (A), Talar (B) and Babolrood (C) rivers in comparison to trigger values established under US EPA Aquatic Life Benchmarks (170 ng/L) and the Australian and New Zealand Guidelines for Fresh and Marine Water Quality (100 ng/L).

\section{Conclusions}

This study presents an initial evaluation of the seasonal and spatial distribution of a widely used OPP, diazinon, in surface water of the three Iran rivers located close to the Caspian Sea (the Haraz, the Talar and the Babolrood rivers), and estimated ecotoxicological risk assessment. The status of the three rivers in the south of the Caspian Sea in the summer seems to be critical due to the use of diazinon for rice cultivation. Our results showed that concentrations of diazinon in summer months (July-August) amounted to $80 \%$ of the total pesticide concentration throughout the whole sampling period (July-December). Such elevated concentrations of the studied pesticide in the riverine water threaten the health of the aquatic organisms and may indirectly impact human health. Hence, the risk posed due to exposure of diazinon in this area cannot be neglected. In the studied rivers, the high 
risks ( $R Q$ values) due to the elevated levels of diazinon were observed. The Babolrood River was found to have the highest $R Q$ values and hence should be given a higher priority. Risk prioritization is important for decision-making in water resource management and policy implementation.

Based on the current study, it is advisable that countries such as Iran should develop their own standards and regulations toward OPPs in order to reduce pollution levels and protect their environment.

Author Contributions: Conceptualization, methodology, software, validation, formal analysis, writing—original draft preparation, R.D.B., investigation, resources, project administration, funding acquisition, A.E.-s.; data curation, writing—review and editing, visualization, supervision, M.U. and P.C. All authors have read and agreed to the published version of the manuscript.

Funding: This research received no external funding.

Institutional Review Board Statement: No human or animal samples were used in this study.

Informed Consent Statement: I understand that the text and any pictures published in the article will be freely available on the internet and may be seen by the general public. The pictures, and text may also appear on other websites or in print, may be translated into other languages or used for commercial purposes.

Data Availability Statement: The authors declared that the data and materials for this work are available.

Acknowledgments: This work was funded by the University of Zabol and Trabiat Modares University.

Conflicts of Interest: The authors declared that there is no conflict of interest among them. All the authors read and approved the manuscript.

\section{References}

1. Alavanja, M.C.R. Pesticides use and exposure extensive worldwide. Rev. Environ. Health 2009, 24, 303-309. [CrossRef] [PubMed]

2. Wee, S.Y.; Aris, A.Z. Ecological risk estimation of organophosphorus pesticides in riverine ecosystems. Chemosphere 2017, 188, 575-581. [CrossRef] [PubMed]

3. López-Blanco, C.; Gómez-Álvarez, S.; Rey-Garrote, M.; Cancho-Grande, B.; Simal-Gándara, J. Determination of carbamates and organophosphorus pesticides by SDME-GC in natural water. Anal. Bioanal. Chem. 2005, 383, 557-561. [CrossRef] [PubMed]

4. Zheng, S.; Chen, B.; Qiu, X.; Chen, M.; Ma, Z.; Yu, X. Distribution and risk assessment of 82 pesticides in Jiulong River and estuary in South China. Chemosphere 2016, 144, 1177-1192. [CrossRef] [PubMed]

5. Tankiewicz, M.; Fenik, J.; Biziuk, M. Solventless and solvent-minimized sample preparation techniques for determining currently used pesticides in water samples: A review. Talanta 2011, 86, 8-22. [CrossRef]

6. Yu, R.; Liu, Q.; Liu, J.; Wang, Q.; Wang, Y. Concentrations of organophosphorus pesticides in fresh vegetables and related human health risk assessment in Changchun, Northeast China. Food Control 2016, 60, 353-360. [CrossRef]

7. Sehonova, P.; Svobodova, Z.; Dolezelova, P.; Vosmerova, P.; Faggio, C. Effects of waterborne antidepressants on non-target animals living in the aquatic environment: A review. Sci. Total Environ. 2018, 631, 789-794. [CrossRef]

8. Faggio, C.; Tsarpali, V.; Dailianis, S. Mussel digestive gland as a model tissue for assessing xenobiotics: An overview. Sci. Total Environ. 2018, 636, 220-229. [CrossRef]

9. Stara, A.; Bellinvia, R.; Velisek, J.; Strouhova, A.; Kouba, A.; Faggio, C. Acute exposure of neonicotinoid pesticide on common yabby (Cherax destructor) to the neonicotinoid pesticide. Sci. Total Environ. 2019, 665, 718-723. [CrossRef]

10. Wang, D.; Weston, D.P.; Lydy, M.J. Method development for the analysis of organophosphate and pyrethroid insecticides at low parts per trillion levels in water. Talanta 2009, 78, 1345-1351. [CrossRef]

11. Ophir, A.; Karakis, I.; Richter, E.D.; Abarbanel, J.M.; Wormser, U.; Aschner, M.; Finkelstein, Y. An uncommon pattern of polyneuropathy induced by lifetime exposures to drift containing organophosphate pesticides. Neurotoxicology 2014, 45, 338-346. [CrossRef]

12. EPA. Aquatic Life Ambient Water Quality Criteria, Diazinon, FINAL; Office of Science and Technology, U.S. Environmental Protection Agency: Washington, DC, USA, 2005; Volume 88.

13. Rao, R.J.; Wani, K.A. Monitoring of organochlorine and organophosphorus pesticide residues in water during different seasons of Tighra reservoir Gwalior, Madhya Pradesh, India. Environ. Monit. Assess. 2015, 187, 684.

14. Thomatou, A.-A.; Zacharias, I.; Hela, D.; Konstantinou, I. Determination and risk assessment of pesticide residues in lake Amvrakia (W. Greece) after agricultural land use changes in the lake's drainage basin. Int. J. Environ. Anal. Chem. 2013, 93, 780-799. [CrossRef] 
15. Poulier, G.; Lissalde, S.; Charriau, A.; Buzier, R.; Cleries, K.; Delmas, F.; Mazzella, N.; Guibaud, G. Estimates of pesticide concentrations and fluxes in two rivers of an extensive French multi-agricultural watershed: Application of the passive sampling strategy. Environ. Sci. Pollut. Res. 2015, 22, 8044-8057. [CrossRef] [PubMed]

16. Dzul-Caamal, R.; Domínguez-Lòpez, M.L.; Olivares-Rubio, H.F.; García-Latorre, E.; Vega-López, A. The relationship between the bioactivation and detoxification of diazinon and chlorpyrifos, and the inhibition of acetylcholinesterase activity in Chirostoma jordani from three lakes with low to high organophosphate pesticides contamination. Ecotoxicology 2014, 23, 779-790. [CrossRef] [PubMed]

17. Kuzmanović, M.; Ginebreda, A.; Petrović, M.; Barceló, D. Risk assessment based prioritization of 200 organic micropollutants in 4 Iberian rivers. Sci. Total Environ. 2015, 503, 289-299. [CrossRef] [PubMed]

18. Masiá, A.; Campo, J.; Navarro-Ortega, A.; Barceló, D.; Picó, Y. Pesticide monitoring in the basin of Llobregat River (Catalonia, Spain) and comparison with historical data. Sci. Total Environ. 2015, 503, 58-68. [CrossRef] [PubMed]

19. Montuori, P.; Aurino, S.; Nardone, A.; Cirillo, T.; Triassi, M. Spatial distribution and partitioning of organophosphates pesticide in water and sediment from Sarno River and Estuary, Southern Italy. Environ. Sci. Pollut. Res. 2015, 22, 8629-8642.

20. Montuori, P.; Aurino, S.; Garzonio, F.; Nardone, A.; Triassi, M. Estimation of heavy metal loads from Tiber River to the Tyrrhenian Sea and environmental quality assessment. Environ. Sci. Pollut. Res. 2016, 23, 23694-23713. [CrossRef]

21. Montuori, P.; Aurino, S.; Garzonio, F.; Sarnacchiaro, P.; Polichetti, S.; Nardone, A.; Triassi, M. Estimates of Tiber River organophosphate pesticide loads to the Tyrrhenian Sea and ecological risk. Sci. Total Environ. 2016, 559, 218-231.

22. Montuori, P.; Aurino, S.; Garzonio, F.; Sarnacchiaro, P.; Nardone, A.; Triassi, M. Distribution, sources and ecological risk assessment of polycyclic aromatic hydrocarbons in water and sediments from Tiber River and estuary, Italy. Sci. Total Environ. 2016, 566, 1254-1267. [CrossRef] [PubMed]

23. Talebi, K. Diazinon residues in the basins of Anzali Lagoon, Iran. Bull. Environ. Contam. Toxicol. 1998, 61, 477-483. [CrossRef] [PubMed]

24. Ghassempour, A.; Mohammadkhah, A.; Najafi, F.; Rajabzadeh, M. Monitoring of the pesticide diazinon in soil, stem and surface water of rice fields. Anal. Sci. 2002, 18, 779-783. [CrossRef]

25. Heidari, H. Farmer field schools (FFS) slash pesticide use and exposure in Islamic Republic of Iran. Agro Chem. Rep. 2003, 3 , 23-26.

26. Rahmanikhah, Z.; Sari, A.E.; Bahramifar, N.; Bousjien, Z.S. Organophosphorous Pesticide Residues in Surface and Ground Water in the Southern Coast Watershed of Caspian Sea, Iran. Middle East J. Sci. Res. 2011, 7, 253-259.

27. Abbasian, H.; Azim, A.; Shamilla, H.; Hamid, G.M. Residues of diazinon in Ab-bandans supplied by Babolroud, Talar and Siaroud Rivers, Iran. J. Ecol. Nat. Environ. 2014, 6, 153-158. [CrossRef]

28. Yousefi, S.; Moradi, H.R.; Keesstra, S.; Pourghasemi, H.R.; Navratil, O.; Hooke, J. Effects of urbanization on river morphology of the Talar River, Mazandarn Province, Iran. Geocarto Int. 2019, 34, 276-292. [CrossRef]

29. Pejman, A.H.; Bidhendi, G.R.N.; Karbassi, A.R.; Mehrdadi, N.; Bidhendi, M.E. Evaluation of spatial and seasonal variations in surface water quality using multivariate statistical techniques. Int. J. Environ. Sci. Technol. 2009, 6, 467-476. [CrossRef]

30. Karbassi, A.R.; Nouri, J.; Bidhendi, G.R.N.; Ayaz, G.O. Behavior of $\mathrm{Cu}, \mathrm{Zn}, \mathrm{Pb}, \mathrm{Ni}$ and Mn during mixing of freshwater with the Caspian Sea water. Desalination 2008, 229, 118-124. [CrossRef]

31. Amiri, M.; Nohegar, A.; Bouzari, S. Potential Assessment of Geomorphological Landforms of the Mountainous Highland Region, Haraz Watershed, Mazandaran, Iran, Using the Pralong Method. Pollution 2018, 4, 381-394. [CrossRef]

32. Safaripour, M.; Monavari, M.; Zare, M.; Abedi, Z.; Gharagozlou, A. Flood Risk Assessment Using GIS (Case Study: Golestan Province, Iran). Pol. J. Environ. Stud. 2012, 21, 1817-1824.

33. Derafshi, K.; Khaledi, S.; Shaebaninia, H.; Mehrjoonezhad, A. The study of land use changes and modeling of precipitation-runoff using HEC-HMS model, Case Study: Babolrood basin. Q. J. Environ. Eros. Res. 2016, 15, 30-44. (In Persian)

34. Hourieh Fallah, S.; Bakaeian, M.; Parsian, H.; Amouei, A.; Asgharnia, H.; Ghanbarian, M.; Mousapour, A.; Tabarinai, H.; Oskoei, V.; Miri, S.A. Potentially harmful heavy metal contamination in Babolrood river: Evaluation for risk assessment in the Mazandaran province, Iran. Int. J. Environ. Anal. Chem. 2020, 12, 1-15. [CrossRef]

35. Tariq, M.I.; Afzal, S.; Hussain, I. Pesticides in shallow groundwater of bahawalnagar, Muzafargarh, DG Khan and Rajan Pur districts of Punjab, Pakistan. Environ. Int. 2004, 30, 471-479. [CrossRef]

36. Albanis, T.A.; Hela, D.G.; Sakellarides, T.M.; Konstantinou, I.K. Monitoring of pesticide residues and their metabolites in surface and underground waters of Imathia (N. Greece) by means of solid-phase extraction disks and gas chromatography. J. Chromatogr. A 1998, 823, 59-71. [CrossRef]

37. Sudo, M.; Kunimatsu, T.; Okubo, T. Concentration and loading of pesticide residues in Lake Biwa basin (Japan). Water Res. 2002, 36, 315-329. [CrossRef]

38. Palma, P.; Köck-Schulmeyer, M.; Alvarenga, P.; Ledo, L.; Barbosa, I.R.; De Alda, M.L.; Barceló, D. Risk assessment of pesticides detected in surface water of the Alqueva reservoir (Guadiana basin, southern of Portugal). Sci. Total Environ. 2014, 488, 208-219. [CrossRef]

39. Xu, W.; Yan, W.; Li, X.; Zou, Y.; Chen, X.; Huang, W.; Miao, L.; Zhang, R.; Zhang, G.; Zou, S. Antibiotics in riverine runoff of the Pearl River Delta and Pearl River Estuary, China: Concentrations, mass loading and ecological risks. Environ. Pollut. 2013, 182, 402-407. 
40. European Commission Technical Guidance Document on Risk Assessment. Inst. Health Consum. Prot. Eur. Chem. Bur. Part II 2003. Available online: http/ / echa.Eur.eu/documents/10162/16960216/tgdpart2_2ed_en.pdf (accessed on 20 June 2003).

41. Lewis, K.A.; Tzilivakis, J.; Warner, D.J.; Green, A. An international database for pesticide risk assessments and management. Hum. Ecol. Risk Assess. Int. J. 2016, 22, 1050-1064. [CrossRef]

42. Sánchez-Bayo, F.; Baskaran, S.; Kennedy, I.R. Ecological relative risk (EcoRR): Another approach for risk assessment of pesticides in agriculture. Agric. Ecosyst. Environ. 2002, 91, 37-57. [CrossRef]

43. Reddy, K.N.; Reddy, H. Pesticide residues in surface water of lakes around Hyderabad, India. Pestic. Res. J. 2010, $22,111-115$.

44. Lari, S.Z.; Khan, N.A.; Gandhi, K.N.; Meshram, T.S.; Thacker, N.P. Comparison of pesticide residues in surface water and ground water of agriculture intensive areas. J. Environ. Health Sci. Eng. 2014, 12, 11. [CrossRef] [PubMed]

45. Ahmadi-Mamaqani, Y.; Khorasani, N.; Talebi, K.; Hashemi, S.H.; Rafiee, G.; Bahadori-Khosroshahi, F. Diazinon Fate and Toxicity in the Tajan River (Iran) Ecosystem. Environ. Eng. Sci. 2011, 28, 859-868. [CrossRef]

46. Fadaei, A.; Dehghani, M.H.; Nasseri, S.; Mahvi, A.H.; Rastkari, N.; Shayeghi, M. Organophosphorous pesticides in surface water of Iran. Bull. Environ. Contam. Toxicol. 2012, 88, 867-869. [CrossRef] [PubMed]

47. Lambropoulou, D.A.; Sakkas, V.A.; Hela, D.G.; Albanis, T.A. Application of solid-phase microextraction in the monitoring of priority pesticides in the Kalamas River (NW Greece). J. Chromatogr. A 2002, 963, 107-116. [CrossRef]

48. Kouzayha, A.; Al Ashi, A.; Al Akoum, R.; Al Iskandarani, M.; Budzinski, H.; Jaber, F. Occurrence of pesticide residues in Lebanon's water resources. Bull. Environ. Contam. Toxicol. 2013, 91, 503-509. [CrossRef]

49. Gao, J.; Liu, L.; Liu, X.; Zhou, H.; Lu, J.; Huang, S.; Wang, Z. The occurrence and spatial distribution of organophosphorous pesticides in Chinese surface water. Bull. Environ. Contam. Toxicol. 2009, 82, 223-229. [CrossRef]

50. Abdel-Halim, K.Y.; Salama, A.K.; El-Khateeb, E.N.; Bakry, N.M. Organophosphorus pollutants (OPP) in aquatic environment at Damietta Governorate, Egypt: Implications for monitoring and biomarker responses. Chemosphere 2006, 63, 1491-1498. [CrossRef]

51. Leong, K.H.; Tan, L.L.B.; Mustafa, A.M. Contamination levels of selected organochlorine and organophosphate pesticides in the Selangor River, Malaysia between 2002 and 2003. Chemosphere 2007, 66, 1153-1159. [CrossRef]

52. Mondal, R.; Mukherjee, A.; Biswas, S.; Kole, R.K. GC-MS/MS determination and ecological risk assessment of pesticides in aquatic system: A case study in Hooghly River basin in West Bengal, India. Chemosphere 2018, 206, 217-230. [CrossRef]

53. Kaushik, C.P.; Sharma, H.R.; Kaushik, A. Organochlorine pesticide residues in drinking water in the rural areas of Haryana, India. Environ. Monit. Assess. 2012, 184, 103-112. [CrossRef] [PubMed]

54. Sharip, Z.; Hashim, N.; Suratman, S. Occurrence of organochlorine pesticides in a tropical lake basin. Environ. Monit. Assess. 2017, 189, 560. [CrossRef] [PubMed]

55. Karyab, H.; Mahvi, A.H.; Nazmara, S.; Bahojb, A. Determination of water sources contamination to diazinon and malathion and spatial pollution patterns in Qazvin, Iran. Bull. Environ. Contam. Toxicol. 2013, 90, 126-131. [CrossRef] [PubMed]

56. Boussabbeh, M.; Salem, I.B.; Hamdi, M.; Fradj, S.B.; Abid-Essefi, S.; Bacha, H. Diazinon, an organophosphate pesticide, induces oxidative stress and genotoxicity in cells deriving from large intestine. Environ. Sci. Pollut. Res. 2016, 23, $2882-2889$.

57. Beane Freeman, L.E.; Bonner, M.R.; Blair, A.; Hoppin, J.A.; Sandler, D.P.; Lubin, J.H.; Dosemeci, M.; Lynch, C.F.; Knott, C.; Alavanja, M.C.R. Cancer incidence among male pesticide applicators in the Agricultural Health Study cohort exposed to diazinon. Am. J. Epidemiol. 2005, 162, 1070-1079. [CrossRef]

58. Jones, R.R.; Barone-Adesi, F.; Koutros, S.; Lerro, C.C.; Blair, A.; Lubin, J.; Heltshe, S.L.; Hoppin, J.A.; Alavanja, M.C.R.; Freeman, L.E.B. Incidence of solid tumours among pesticide applicators exposed to the organophosphate insecticide diazinon in the Agricultural Health Study: An updated analysis. Occup. Environ. Med. 2015, 72, 496-503. [CrossRef]

59. Flores, L.; Banjac, Z.; Farré, M.; Larrañaga, A.; Mas-Marti, E.; Muñoz, I.; Barceló, D.; Elosegi, A. Effects of a fungicide (imazalil) and an insecticide (diazinon) on stream fungi and invertebrates associated with litter breakdown. Sci. Total Environ. 2014, 476, 532-541. [CrossRef]

60. Stamatis, N.; Hela, D.; Triantafyllidis, V.; Konstantinou, I. Spatiotemporal variation and risk assessment of pesticides in water of the lower catchment basin of Acheloos River, Western Greece. Sci. World J. 2013, 2013, 1-16.

61. Geissen, V.; Mol, H.; Klumpp, E.; Umlauf, G.; Nadal, M.; van der Ploeg, M.; van de Zee, S.E.; Ritsema, C.J. Emerging pollutants in the environment: A challenge for water resource management. Int. Soil Water Conserv. Res. 2015, 3, 57-65. [CrossRef]

62. Walker, C.H.; Sibly, R.M.; Hopkin, S.P.; Peakall, D.B. Principles of Ecotoxicology; CRC Press: Boca Raton, FL, USA, 2012.

63. Laetz, C.A.; Baldwin, D.H.; Hebert, V.R.; Stark, J.D.; Scholz, N.L. Elevated temperatures increase the toxicity of pesticide mixtures to juvenile coho salmon. Aquat. Toxicol. 2014, 146, 38-44. 